\title{
Association of rs235768 A>T polymorphism of the bone morphogenetic protein 2 gene on non-syndromic orofacial cleft in an Indonesian population
}

\author{
Rarasih Kiranahayu' ${ }^{1}$, Antonius Winoto Suhartono', Lilies Dwi Sulistyani², Benny \\ Sjariefsyah Latief ${ }^{2}$, Elza Ibrahim Auerkari ${ }^{1 *}$ \\ 'Department of Oral Biology, Faculty of Dentistry University of Indonesia, Indonesia \\ ${ }^{2}$ Department of Oral and Maxillofacial Surgery, Faculty of Dentistry University of Indonesia, \\ Indonesia
}

\begin{abstract}
Introduction: Orofacial cleft is one of the many congenital malformations that often occur in human, leaving it at the fourth level of the most common orofacial birth defect findings. The incident rate is one in 700-1000 deliveries, where without therapeutic and surgical interventions, children with an orofacial cleft may have problems with speech, nutrition intake, and growth. Bone morphogenetic protein 2 (BMP2) gene play essential roles in the migration and proliferation of neural crest cell of the early head formation and regulate mineralised tissues such as maxillary, mandible, palate and teeth. This study was aimed to analyse the BMP-2 polymorphism and its potential association with orofacial cleft in an Indonesian population. Methods: Cross-sectional study was conducted towards 128 samples, 32 samples of orofacial cleft patients and 96 samples of control. Extracted genotype and allele was determined with PCR-RFLP method using stored DNA samples from 32 orofacial cleft patients, and 96 healthy control. Results: The TT genotype was showing the $\mathrm{p}$-value $=0.001, \mathrm{OR}=2.43 \%$ in orofacial samples $(71.4 \%)$, which was significantly higher than in control groups $(28.6 \%)$. The allele distribution was also considered statistically significant $(p=0.036, O R=1.89 \%$. Conclusion: There is a significant association of $r s 235768$ $A>T$ polymorphism of the BMP-2 gene on non-syndromic orofacial cleft patients in Indonesia.
\end{abstract}

Keywords: Bone morphogenetic protein 2 (BMP-2), polymorphism, non-syndromic orofacial cleft, Indonesia.

p-ISSN: 1979-0201; e-ISSN: 2549-6212; Available from: http://jurnal.unpad.ac.id/pjd/article/view/23917

DOI: $10.24198 /$ pid.vol32no2.23917

Submission: Oct 15, 2019; Accepted: Jul 19, 2020; Published online: Jul 31, 2020

"Corresponding author: Elza Ibrahim Auerkari, Department of Oral Biology, Faculty of Dentistry University of Indonesia, Indonesia. Department of Oral Biology, Faculty of Dentistry University of Indonesia, Universitas Indonesia Kampus, Jalan Salemba Raya IV, Central Jakarta, Special Capital Region of Jakarta, Indonesia, 10430. Phone: +6281284392420; Email: eauerkari@yahoo.com 


\section{INTRODUCTION}

Orofacial cleft is one of the many congenital malformations that often occur in humans. Cleft lip and palate, which is a defect in the orofacial part, is one of the developmental deformities commonly found in oral and maxillofacial surgical clinics. This bring orofacial cleft at the fourth level of the most commonly found birth defects in the face characterized by a morphological abnormality that can alter the facial structure and affect the anatomical structure, as well as muscle function with varying severity. ${ }^{1-3}$ Cleft lip arises due to a fusion failure between medial nasal process and maxillary process at 4-6 embryonal weeks. While cleft palate occurs due to the presence of fusion failure between the primary palate and the secondary palate at week 8-12 embryonal. ${ }^{4}$ Whereas, without therapeutic and surgical management, children with cleft lip and palate will experience significant obstacles in speech, nutrition, and developmental growth that will affect their life in general. ${ }^{5}$

Based on the study, orofacial cleft is reported to have an incident rate of one in 7001000 deliveries. ${ }^{1}$ Where the incidence rate of orofacial cleft in Asian and Indian-American races is higher than Caucasian and African race. ${ }^{6}$ In Indonesia, cleft lip and palate are still considered a problem where one in 1000 live births have cleft lip. Reportedly, by 2016, it is estimated that 9,500 children have cleft lip and/ or with a cleft palate, and the number is expected to increase every year. ${ }^{7}$ Divided by its particular malformative pattern or its emergence as isolated orofacial defects, orofacial cleft is classified into syndromic orofacial cleft and non-syndromic orofacial cleft. Both forms of orofacial cleft have a strong genetic component. The syndromic form caused by chromosomal abnormalities or monogenic disease while non-syndromic form caused by complex interaction of genetic and environmental. ${ }^{8}$

The genetic factors causing orofacial cleft may include chromosomal abnormalities, genetic susceptibility to teratogenic exposure, and the complex contribution of various genes. In addition to genetic factors, high tongue position, increased face width, alcohol and drug abuse, vitamin deficiency, especially folic acid during the first week of pregnancy, maternal age, and the presence of maternal diabetes mellitus can also trigger orofacial cleft. ${ }^{2}$

BMP-2 gene is one of the gene that plays role in maturation and ossification of the fusion of the palate. ${ }^{4}$ BMP-2 gene, is located on 20p12.3, where this gene starts at $6,767,664 \mathrm{bp}$ from the promoter and ends at $6,780,280 \mathrm{bp}$ of the promoter. It has a size of 396 amino acids, 12,617 bases, and a mass of molecules weighing $44702 \mathrm{Da}$. This gene is also known to have a contribute in a role of neural crest cells migration and proliferation of early head formation, facial pattern formation, and regulated mineralized tissues such as cranial, maxillary, mandibular, palate and teeth \#1. Some polymorphisms or mutations that occur in BMP. 2 signaling pathway may cause morphogenesis disorders of a palate. ${ }^{9}$ Recently, two individuals with similar orofacial cleft defects experienced polymorphisms that only occurred in the BMP-2 rs235768 A>T gene have been found. ${ }^{1}$ This study was aimed to analyse the BMP2 polymorphism and its potential association with orofacial cleft in Indonesian population. Polymorphism of the BMP2 might play a specific role in the occurrence of orofacial cleft.

\section{METHODS}

A cross sectional study of a total 128 stored DNA samples that had been extracted from peripheral blood taken from the Indonesian population using the techniques by Auerkari et al. ${ }^{10-13}$, which were made available from the Laboratory of Oral Biology, Faculty of Dentistry University of Indonesia. This research has obtained approval from the Ethics Commission of the Faculty Dentistry University of Indonesia with the number of 77/Ethical Approval/ FKGUI/VII/2017, protocol No. 010580717. Polymorphism of BMP-2 rs235768 A>T was obtained by using PCR-RFLP method with spesific forward primer and reverse primer (Genetika Science) 5'-GAAACGAGTGGGAAAACAACC-3' and 5'GAGACACCTTGTTTCTCCTCCA-3', respectively. The expected PCR product is $353 \mathrm{bp}$.

A total volume of $20 \mu \mathrm{l} \mathrm{PCR}$ mix contained $10 \mu \mathrm{l}$ KAPA taq ReadyMix PCR with dye (Kapa Biosystem), reverse and forward primers $0,4 \mu \mathrm{l}$ each, $9 \mu \mathrm{l}$ sterile distilled water and 0,2 $\mu \mathrm{l}$ DNA template, then amplified with thermocycler (BioRadCycler). The amplification used an annealing 
condition at $62^{\circ} \mathrm{C}$ for 30 seconds for 33 cycles followed by elongation at $72^{\circ} \mathrm{C}$ for 40 seconds. Electrophoresis was conducted using $2 \%$ of agarose gel (Bioline) at $70 \mathrm{~V}, 400 \mathrm{~mA}$, for 40 minutes.

After successfully authenticated by observing the result of electrophored agarose, the RFLP method was run using the Bsrl restriction enzyme. The RFLP mixture was incubated at $65^{\circ} \mathrm{C}$ for 15 minutes, followed by inactivation at the temperature of $80^{\circ} \mathrm{C}$ for 20 minutes. $2.5 \%$ agarose gel then prepared to help visualized the DNA band at $70 \mathrm{~V}, 400 \mathrm{~mA}$ for 50 minutes. Gel was observed and documented using the Gel-Doc (Bio-Rad). $1 \mu \mathrm{l}$ $(33.33 \mu \mathrm{mol}) \mathrm{Gel}$ Red Nucleic Acid Gel Stain 10,000x in Water (GelRed ${ }^{\top M}$ ) was added every time into the agarose gel to help visualized under the UV light. After visualization of the RFLP mix was obtained, three possible genotype can be observed, $353 \mathrm{bp}$ for wildtype homozygote (AA), $353 \mathrm{bp}, 200 \mathrm{bp}$ and 153 bp for mutant heterozygote (AT), 153 bp and 200 bp for mutant homozygote (TT) All statistical analysis was permormed using IBM $®$ SPSS $®$ (SPSS Inc., IBM Corporation, NY, USA) Statistics Version 22.

The Chi-Square $\left(\mathrm{X}^{2}\right)$ test was used for analysing the genotype distribution between both groups. Allele distribution between both groups and descriptive analysis for polymorphic and non-polymorphic genotype were assessed using Continuity Correction and Fisher's Exact tests, respectively. Analysed frequencies for both genotype and allele were calculated and assessed for Hardy Weinberg Equilibrium, where the $\mathrm{p}$-value $<0.05$ were considered having statistically significant difference in all cases.

\section{RESULTS}

After amplification of DNA followed by electrophoresis, the PCR product was obtained by visualization using Gel-Doc. DNA ladder $50 \mathrm{bp}$ (Thermoscientific) was used to help determine the target. Figure 1 shows the electrophoresis results of PCR products in which each of the visible DNA bands located at $353 \mathrm{bp}$ indicating a single band as the intended target.

Restriction of PCR product amplification results to obtain genotype and allele frequencies from each sample was obtained by using RFLP (Restriction Fragment Length Polymorphism) method using restriction $B s r l$ enzyme. This enzyme will cut the DNA bands in a specific sequence, resulting in fragments on a particular target. If the restriction enzyme recognizes the A-allele there will be no restriction, so that a DNA band of $353 \mathrm{bp}$ will remain, if the restriction enzyme recognizes the T-allele, then the DNA band will be obtained at $153 \mathrm{bp}$ and $200 \mathrm{bp}$. Thus, the homozygous wildtype (AA) genotype will show a single DNA band at $353 \mathrm{bp}$. The heterozygous (AT) genotype will show the DNA band fragments at 353 bp, $200 \mathrm{bp}$ and $153 \mathrm{bp}$. Meanwhile, homozygous mutant (TT) will show DNA band fragments at 153 bp and $200 \mathrm{bp}$. Figure 2 shows the electrophoresis results of RFLP products showing three different genotypes.

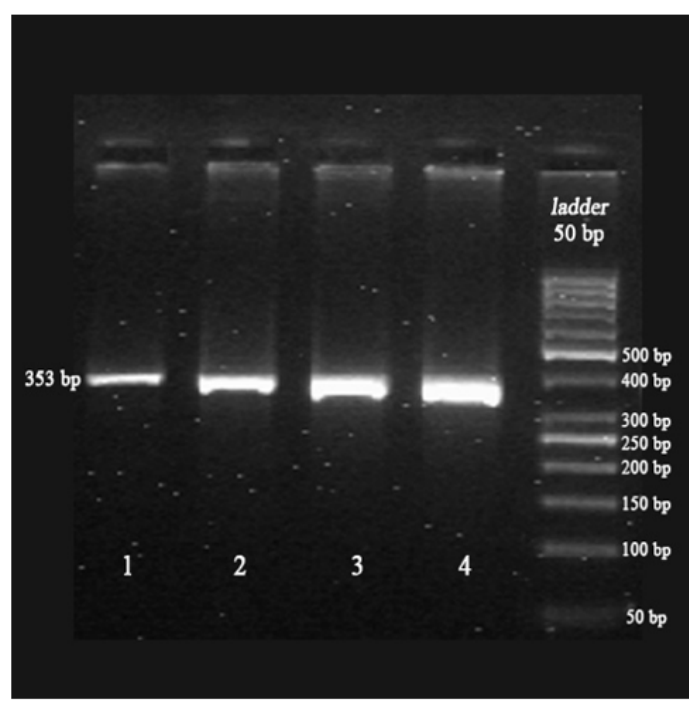

Figure 1. The results of PCR product after electrophoresis, indicating a single band at $353 \mathrm{bp}$.

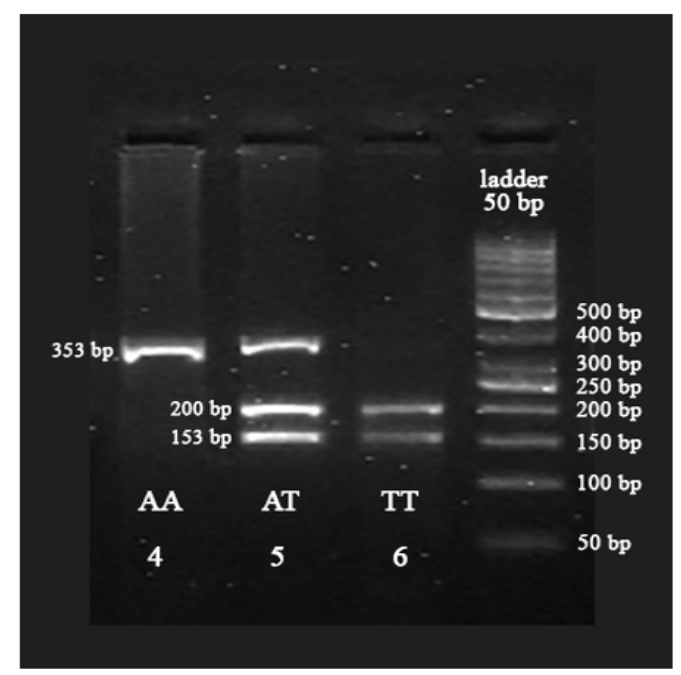

Figure 2. The results of RFLP product after electrophoresis, lane 4, 5 and 6 indicating AA, AT, and TT genotype, respectively. 
Distribution of genotypes in the orofacial cleft group showed that from the total of 32 orofacial cleft samples, 1 sample had homozygous wildtype (AA) genotypes, 21 samples had heterozygous (AT) genotypes, and 10 samples had homozygous mutant (TT) genotypes. While in the control group, from the total of 96 control samples, 7 samples had homozygous wildtype (AA) genotypes, 85 samples had heterozygous (AT) genotypes, and 4 samples had homozygous mutant (TT) genotypes.

Based on the result of Hardy-Weinberg Equilibrium equation, the distribution of genotype using Chi-Square showed that there was a significant genotype distribution of BMP2 rs235768 $A>T$ polymorphism $(p=0.001, O R=$ $2.43 \%)$. The genotype distribution of BMP-2 gene rs235768 A> T in the orofacial cleft group and the control group shows in Table 1.

Table 1. Genotype distribution of rs235768 A> T polymorphism of BMP-2 gene on non-syndromic orofacial cleft and control group

\begin{tabular}{ccccc}
\hline & \multicolumn{3}{c}{ Genotype frequencies } & \\
\cline { 2 - 4 } & AA (\%) & AT (\%) & TT (\%) & P-value \\
\hline Orofacial & 1 & 21 & 10 & \\
& 12.5 & 19.8 & $71.4 \%$ & 0.001 \\
Control & 7 & 85 & 4 & \\
& $87.5 \%$ & $80.2 \%$ & $28.6 \%$ & \\
Total & 8 & 106 & 14 & \\
\hline Genotype & $100 \%$ & $100 \%$ & $100 \%$ & \\
\hline
\end{tabular}

In addition to the genotype, from the results of the study, there were 111 of the control group and 23 of the orofacial cleft group having A-allele or non-polymorphic alleles. Whereas, there were 103 of the control group and 64 of the orofacial cleft group had T-alleles or polymorphic alleles. The Continuity correction test result showed a significant difference in allele distribution $(\mathrm{p}=$ $0.036, \mathrm{OR}=1.89 \%$ ). The distribution of allele in both groups shown in Table 2 .

In this study, a total 31 from 32 orofacial cleft samples have been indicated to have a mutant allele $(\mathrm{T})$, while 89 samples from 96 control samples also have been indicated to have a mutant allele, which found in mostly mutant heterozygote for 85 samples. With $p=0.001$ for genotype and $p=0,036$ for allele, these results showed an involvement of the polymorphism possibility in orofacial cleft patient.

Table 2. Allele distribution of BMP-2 gene rs235768 A> T in orofacial cleft and control group

\begin{tabular}{|c|c|c|c|}
\hline & \multicolumn{2}{|c|}{ Allele frequency } & \multirow{2}{*}{ P-value } \\
\hline & $A(\%)$ & $\mathrm{T}(\%)$ & \\
\hline \multirow{2}{*}{$\begin{array}{c}\text { Orofacial } \\
\text { Cleft }\end{array}$} & 23 & 41 & \\
\hline & $17.2 \%$ & $28.5 \%$ & 0.025 \\
\hline \multirow[t]{2}{*}{ Control } & 111 & 103 & \\
\hline & $82.8 \%$ & $71.5 \%$ & \\
\hline Total & 134 & 144 & \\
\hline Allele & $100 \%$ & $100 \%$ & \\
\hline
\end{tabular}

\section{DISCUSSION}

Orofacial clefts are one of the most common craniofacial birth defects that occur in human. The aetiology is still considered complex with genetic and environmental factors, and both having significant roles. ${ }^{14}$ The identification of genetic factors associated with cleft lip and or palate has been a goal of numerous research groups. An environmental factor of clefting has also been recognised, especially in the population with low socioeconomic status. The BMP signalling pathway regulates a wide array of developmental processes such as cell proliferation, apoptosis, differentiation, and morphogenesis. ${ }^{15}$ In this study, using 32 samples of orofacial cleft patients and 96 samples of control, 31 from 32 orofacial cleft samples have been indicated to have a mutant allele (T) (control group), while 89 samples from 96 control samples also have been indicated to have a mutant allele. This result shows the possibility of BMP2 polymorphism involvement on the orofacial cleft patient.

Recent other studies of BMP2 gene rs235768 $A>T$ on orofacial cleft has been taken place. A previous study in Tehran, $\operatorname{Iran}^{16}$, with a total sample of 107 orofacial cleft and 186 controls showed that BMP2 gene rs235768 A> T genotype was significantly higher $(p=0.009, O R=3.95 \%)$ between both groups. At the same time, the allele distribution was also significantly higher than the control group, which indicated the $T$ allele as a risk factor, with $O R=2.2 \%$. The present study was the first study that showed the association between the BMP2 gene rs235768 A> T with orofacial cleft. 
Another study also shows the association of BMP gene and orofacial cleft, but not the same BMP gene as in this study and the Iranian population study.

The BMP4 rs17563 T>C was studied in a Chinese population ${ }^{17}$, where they find no significant association between BMP4 rs17563 T>C and orofacial cleft. Study in Karnataka, India, with a total sample of 200, 100 for each group shows that there was a significant difference with $\mathrm{p}<$ $0.05, \mathrm{OR}=4.2 \%$. Moreover, there was a difference in basepair found in this recent study in Indonesia than in one of the previous studies. The basepair shown were $353 \mathrm{bp}, 200 \mathrm{bp}$, and $153 \mathrm{bp}$, which were not the same as in Tehran, India that shows $165 \mathrm{bp}$ for AA homozygote wildtype genotype, $87 \mathrm{bp}$ and $79 \mathrm{bp}$ for TT homozygote variant/ polymorphic genotype and $165 \mathrm{bp}, 86 \mathrm{bp}$ and79 bp for AT heterozygote genotype. In contrast, both study still shows the same result where there is a significant difference between the orofacial cleft group and the control groups. ${ }^{18}$

While Suzuki et al..$^{19}$ in China, have identified missense and nonsense mutations in the BMP4 gene. One of 30 cases detected having microform clefts, 2 of 87 cases having subepithelial defects in the orbicularis oris muscle, and 5 of 968 cases of overt cleft lip palate, and 0 of 529 controls. Confirmation that microforms and subepithelial orbicularis oris muscle defects are part of the spectrum of cleft lip palate obtained from this research.

\section{CONCLUSION}

There is a significant association of rs235768 A>T polymorphism of the BMP-2 gene on non-syndromic orofacial cleft patients in Indonesia.

\section{ACKNOWLEDGMENT}

The authors wish to gratefully acknowledge the financial support from the Indonesian Ministry of Education through the University of Indonesia (EIA).

\section{REFERENCES}

1. Dixon MJ, Marazita ML, Beaty TH, Murray JC. Cleft lip and palate: Synthesizing genetic and environmental influences. Nat Rev Genet. 2011; 12(3): 167-78. DOI: $10.1038 / \mathrm{nrg} 2933$

2. Shaikh AH, Ibrahim MW, Bukhari G, Taqi M. Demographic profile of cleft lip \& palate patients. Pak Oral Dent J. 2017; 37(1): 16-8.

3. Crês MC, Marques IL, Bettiol H. Evaluation of delayed puberty in adolescents with cleft lip/ palate. Cleft Palate Craniofac J. 2016; 53(4): 464-8. DOI: $10.1597 / 14-175$

4. Bath-Balogh M, Fehrenbach MJ. Dental Embryology, Histology, and Anatomy. $3^{\text {rd }}$ ed. Philadelphia: Saunders-Elsevier; pp. 54-55.

5. Cildir SK, Sandalli N, Nazli S, Alp F, Caglar E. A novel delivery system of probiotic drop and its effect on dental caries risk factors in cleft lip/palate children. Cleft Palate Craniofacial J. 2012; 49(3): 369-72. DOI: 10.1597/10-035

6. Feng $C$, Zhang E, Duan W, Xu Z, Zhang Y, Lu L. Association between polymorphism of TGFA Taq I and cleft Lip and/or palate: A metaanalysis. BMC Oral Health. 2014; 14: 88. DOI: 10.1186/1472-6831-14-88

7. National Institute of Health Research and Development (NIHRD). Indonesia Basic Health Research (RISKESDAS) 2012-2013. Jakarta: Ministry of Health of the Republic of Indonesia; 2013.

8. Stuppia L, Capogreco M, Marzo G, La Rovere D, Antonucci I, Gatta V, et al. Genetics of syndromic and nonsyndromic cleft lip and palate. J Craniofac Surg. 2011; 22(5): 1722-6. DOI: $10.1097 /$ SCS.0b013e31822e5e4d

9. Graf D, Malik Z, Hayano S, Mishina Y. Common mechanisms in development and disease: BMP signaling in craniofacial development. Cytokine Growth Factor Rev. 2016; 27: 129-39. DOI: $10.1016 / j . c y t o g f r .2015 .11 .004$

10. Auerkari El, Suhartono AW, Djamal NZ, Verisqa F, Suryandari DA, Kusdhany LS, et al. CRP and IL-1B gene polymorphisms and CRP in blood in periodontal disease. Open Dent J. 2013; 7: 8893. DOI: $10.2174 / 1874210601307010088$

11. Tanjaya J, Auerkari El. IL-1B genetic polimorphism in menopause women as periodontal disease risk factor. J Dent Ind. 2011; 18(1): 1-5. DOI: 10.14693/jdi.v18i1.52

12. Auerkari El, Kusdhany LS, Umami SS, Rahardjo TBW, Talbot C. Polymorphism of methylenetetrahydrofolate reductase (A1298C) as a risk factor for osteoporosis in 
post-menopausal Indonesian women. Asian J Pharm Clin Res. 2017; 10(10): 172-5. DOI: 10.22159/ajpcr.2017.v10i10.20272

13. Tania SF, Kim KR, Suhartono AW, Latief BS, Auerkari El. Distribution of E-cadherin 1 (CDH1) promoter methylation in patients with orofacial cleft. J Phys Conf Series. 2018; 1073: 032064. DOI: 10.1088/17426596/1073/3/032064

14. Sahoo T, Theisen A, Sanchez-Lara PA, Marble M, Schweitzer DN, Torchia BS, et al. Microdeletion 20p12.3 involving BMP2 contributes to syndromic forms of cleft palate. Am J Med Genet A. 2011; 155(7): 1646-53. DOI: $10.1002 /$ ajmg.a.34063

15. Parada C, Chai Y. Roles of BMP signaling pathway in lip and palate development. Front Oral Biol. 2012; 16: 60-70. DOI: 10.1159/000337617

16. Saket M, Saliminejad K, Kamali K, Moghadam FA, Anvar NE, Khorshid HRK. BMP2 and BMP4 variations and risk of non-syndromic cleft lip and palate. Arch Oral Biol. 2016; 72: 134-7. DOI: $10.1016 /$ j.archoralbio.2016.08.019

17. Savitha S, Sharma SM, Veena S, Rekha R. Single nucleotide polymorphism of BMP4 gene: A risk factor of non-syndromic cleft lip with or without cleft palate. Indian J Plast Surg. 2015; 48(2): 159-64. DOI: 10.4103/09700358.163053

18. Tasadduq R, Murtaza BN, Bibi A, Shakoori AR. BMP-2 polymorphism C. 893T > A (rs235768) does not affect bone mineral density in female population of Lahore. Pak J Zool. 2014; 46(1): 261-6.

19. Suzuki S, Marazita ML, Cooper ME, Miwa N, Hing A, Jugessur A, et al. Mutations in BMP4 are associated with subepithelial, microform, and overt cleft lip. Am J Hum Genet. 2009; 84(3): 406-11. DOI: 10.1016/j.ajhg.2009.02.002 